\title{
Effects of Galohgor Nutraceutical Lactation Cookies on Breast Milk Volume and Lactose Concentration
}

\author{
Katrin Roosita ', ${ }^{1}$ Bahriyatul Ma'rifah², Naufal Muharam Nurdin', Faisal Anwar' \\ 'Department of Community Nutrition, Faculty of Human Ecology, IPB University, Bogor, Indonesia \\ ${ }^{2}$ Department of Nutrition, Faculty of Health Sciences, Universitas Kusuma Husada Surakarta, Surakarta, Indonesia
}

\begin{abstract}
Background: Galohgor nutraceutical lactation cookies (NLC) contain polyherbal which is believed and consumed by postpartum mothers of Sundanese Ethnic in Indonesia to increase breast milk production. This study was aimed to analyze the effects of NLC cookies on breast milk volume and lactose concentrations of postpartum mothers.

Methods: The experimental study with post-controlled design was conducted. Twenty eligible mother-infant pairs were enrolled and divided into two groups. They were randomly assigned to receive NLC $(n=9)$ or original cookies (ORC, $\mathrm{n}=11$ ). Each subjects consumed 4 pieces/d of NLC which containing $1 \mathrm{~g}$ galohgor nutraceutical powder/ pieces or ORC (without galohgor nutraceutical powder), for 14 days intervention period since the first day of giving birth. The measurement of breast milk production was carried out by baby weighing method using SECA 334 digital baby scale (SECA, Hamburg, Germany). A high-performance liquid chromatography method was used to determine lactose concentrations in breast milk. Data were analyzed by parametric Independent T-test or the nonparametric Mann-Whitney U-test and adjusted analysis of covariance.

Results: NLC significantly increased $(\mathrm{P}<0.05)$ breast milk production, as shown by average breast milk volume of NLC compared to ORC, i.e., 557.0 (95\% confidence interval [CI], 497.3-616.6) mL/d vs. 435.9 (95\% CI, 382.3-489.6) $\mathrm{mL} / \mathrm{d}$. This result was supported by lactose concentration in breast milk of mothers who consumed NLC significantly higher ( $\mathrm{P}<0.05)$, compared to ORC, i.e., 6.03\% (95\% CI, 5.66\%-6.40\%) vs. 5.18\% (95\% CI, 4.85\%-5.51\%). Conclusion: NLC which containing galohgor nutraceutical can be recommended to increase breast milk volume and lactose concentration in the early postpartum period.
\end{abstract}

Keywords: Breast Milk; Galactagogue; Lactose; Nutraceuticals; Postpartum

Received: September 10, 2020, Revised: November 21, 2020, Accepted: November 27, 2020

*Corresponding Author: Katrin Roosita https://orcid.org/0000-0002-0734-7336

Tel: +62-812-1812-643, Fax: +62-251-8627-448, E-mail: kroosita2@apps.ipb.ac.id 


\section{INTRODUCTION}

The World Health Organization has strongly recommend exclusive breast feeding for 6 months of early life in order to give adequate nutrients of infants, and continued by complementary feeding that should be added by breast milk for 2 years. ${ }^{1)}$ Breast milk has been accepted as the gold standard of infant nutrition. Adequate breast milk production of mother is very essential for the successful of breast feeding. Early breast milk production has been shown to significantly affect breast milk production during established lactation period. ${ }^{2)}$

Many cultures believe that certain food increase breast milk production during breastfeeding. Galohgor nutraceutical is a traditional nutraceutical made of 56 kinds of plants that contains $\beta$-carotene, bioactive compounds, and other various nutrients. This nutraceutical is usually consumed by Sundanese Villager in Indonesia to increase milk production, to promote uterine involution and health status of postpartum mothers. ${ }^{3,4)}$

Our preclinical study showed that galohgor nutraceutical which contain $\beta$-carotene induce differentiation and function of the mammary gland cell line (HC11). ${ }^{5)}$ Meanwhile, several studies showed that $\beta$-carotene increase connexin ( $\mathrm{Cx} 43)$ gene expression and gap junction intracellular communication (GJIC) which leads to cell differentiation. ${ }^{6,7)}$ GJIC is a channel like structure in the cell membrane that is developed by connexin that maintain cell membrane permeability, regulates cell metabolism, and differentiation. During lactation, the development of the mammary gland GJIC is very critical for sustain- ability of breast milk production., ${ }^{8,9)}$

Practically, the total volume as amount of milk production is a key element defining lactation performance. Lactose, a $\beta$-disaccharide consisting of glucose and galactose, is the most principal carbohydrate in human milk (90\%-95\%). Of all mammals, lactose is present in the highest concentration in the milk of humans (approximately $7 \mathrm{~g} 100$ $\mathrm{mL}-1$ ), corresponding to the high energy demands of the human brain. ${ }^{10)}$ Many previous studies indicated that the rate of lactose synthesis is a major controlling factor of breast milk production. ${ }^{11)}$

Understanding volume and lactose concentration of breast milk provide an important tool for management of infant feeding. Meanwhile, the effect of nutraceutical lactation cookies on breast milk production and lactose concentration of breast milk has not been studied. The objective of this study was to evaluate the effect of nutraceutical lactation cookies effects on breast milk production and lactose concentration of breast milk in early postpartum period.

\section{METHODS}

\section{Subjects and Study Design}

This study was experimental study with post-controlled design. The study protocol was approved by Committee of Human Rights Related to Research Involving Human Subjects, IPB University, Indonesia (No.081/IT3.KEPMSM-IPB/SK/2018). All subjects were informed and gave their consent before enrollment.

This study was conducted at Primary Health Care Center, Bogor

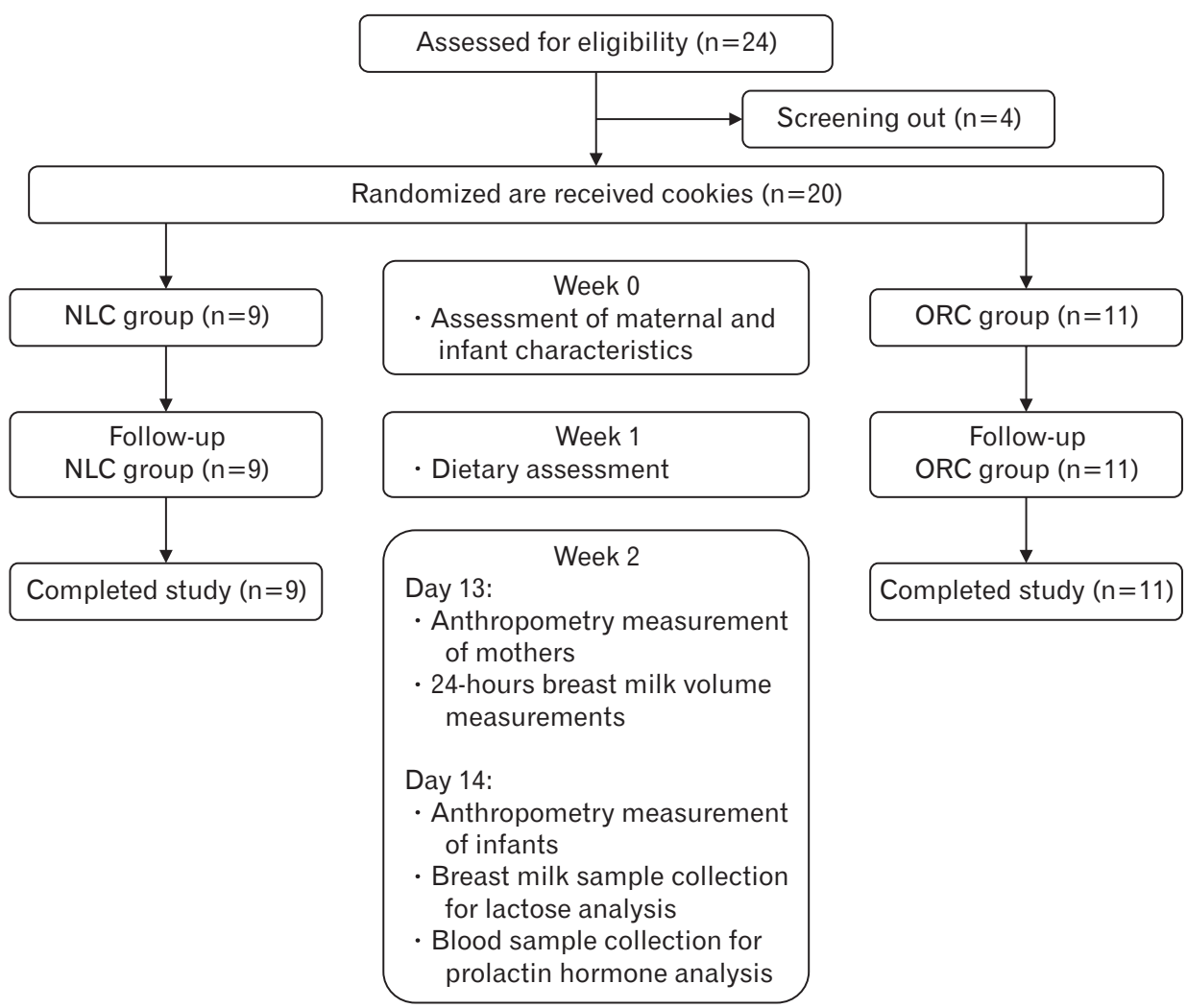

Figure 1. Diagram showing the flow of subjects in Galohgor nutraceutical lactation cookies (NLC) and original cookies (ORC) group. 
City, West Java Province, Indonesia. A total of 24 registered breastfeeding mother-infant pairs were screened, 20 were enrolled. The subjects included aged between 26 to 40 years, single pregnancy, normal delivery, multiparous, having willingness to exclusively breastfeed their infants, and having consented to follow-up visits.

Subjects were excluded if they were having any medical condition or complications during previous pregnancies or delivery, having breast problems such as inverted nipples and mastitis and using a medicine, smoking, drinking alcohol, and being separated from their infant. All infants enrolled into the study were term and healthy neonates. Infants with low birth weight, intrauterine growth retardation and any illness or congenital abnormalities were excluded. After the initial screening visit, 20 eligible subjects were randomly assigned to receive galohgor nutraceutical lactation cookies (NLC, $n=9$ ) or original cookies (ORC, n=11) (Figure 1). Randomization was done according to computer-generated random number sequence. Cookies intervention groups were allocated by research assistant. Participants and principal investigators were blinded to group allocation.

\section{Intervention Procedure}

The subjects received 4 pieces ( $40 \mathrm{~g}$ ) per day of NLC or ORC. NLC contained 1 g galohgor nutraceutical powder per pieces. The galohgor nutraceuticals powder has been already registered on Indonesian patent number IDP000058958. ${ }^{12)}$ NLC were made by CV Nutrasetikal Galohgor (NutriLaktasi, Jakarta, Indonesia) using a cookies formulation that has been acknowledged as a household food production unit. ORC was manufactured without galohgor nutraceutical powder and matched to the NLC in size, shape, and color (as placebo). The nutrient composition of the NLC and ORC cookies is presented in Table 1. All subjects took the assigned cookies for 2 weeks intervention period starting on the first day of giving birth. They were asked to maintain their usual food intake throughout intervention study. We also investigated subject's diary administration and cookies count (both NLC and ORC) every visit to monitor compliance.

\section{Characteristics of Subjects}

We collected maternal and infant characteristics data including maternal age, parity, gestational age, education, socio-economic status (family size and wealth status), and gender of infants by interview using questionnaires at the initial (week 0) visits (Figure 1). Anthropo-

Table 1. Nutrient composition of the ORC and NLC cookies (100 g)

\begin{tabular}{lrr}
\hline \multicolumn{1}{c}{ Components } & ORC & NLC \\
\hline Moisture (\%) & 4.00 & 3.44 \\
Ash (\%) & 2.22 & 2.38 \\
Protein (\%) & 5.13 & 6.22 \\
Fat (\%) & 26.35 & 29.22 \\
Total carbohydrate (\%) & 62.30 & 58.30 \\
Energy (kcal) & 506.87 & 521.06 \\
Beta carotene (mcg/100 g) & 56.00 & 146.00 \\
\hline
\end{tabular}

ORC, original cookies; NLC, Galohgor nutraceutical lactation cookies. metric measurements of mothers were obtained through a physical examination on day 13. Height was measured to the nearest precision of $1 \mathrm{~mm}$ by using a stature meter whilst body weight was measured with minimum clothing to the nearest precision of $0.1 \mathrm{~kg}$ by using a Camry digital weighing scale (Camry Co., Zhongshan, China). Body mass index (BMI, $\mathrm{kg} / \mathrm{m}^{2}$ ) was calculated to determine nutritional status of the mothers. Body fat percentage was measured using bioelectrical impedance analyzer (Omron Co., Kyoto, Japan). The maternal prolactin level was measured on the second week of postpartum period (day 14) in Prodia Laboratory, Bogor, Indonesia. A fasting blood sample was drawn by a research nurse during 8-9 AM of the visit day. Infant anthropometric data (weight, length, and head circumference) were obtained on day 14 . Weight and length of infant were measured by using digital baby scale (SECA 334 and SECA 232; SECA, Hamburg, Germany) meanwhile head circumference was measured by using standard measuring tape.

\section{Dietary Assessment}

Dietary intake was assessed by using 24 hours recall method, conducted twice for each subject for nonconsecutive days on week 1 (Figure 1). We determined the results of the two evaluations by calculating the mean of dietary intake from two non-consecutive 24 hours recall during a time span of a week. The food recalls provided information on portion size using household measures and quantities (g). Dietary intake was calculated with the nutrient content of the consumed intervention cookies. Calculation of energy and macronutrient intake was based on Indonesian Food Composition Database. Macronutrient intake was analyzed using Nutrisurvey 2007 software package downloaded from www.nutrisurvey.de.

\section{24-Hours Breast Milk Volume Measurement}

Breast milk intake measurement were based on Brown et al. ${ }^{13)}$ In test weighing, infants are typically weighed before and after each feeding without a change of clothing or diapers during 24-hour period recorded. The difference in body weight (in grams) is considered to approximate the volume of milk consumed (in $\mathrm{mL}$ ) after multiplying by 0.983 $\mathrm{mL} / \mathrm{g}$ to adjust for the density of breast milk. The weight of the infants was measured using a baby electronic weighing scale accurate to $\pm 10 \mathrm{~g}$ (SECA 334; SECA). The scale was periodically checked for its accuracy by a calibration weight.

\section{Breast Milk Sample Collection}

Breast milk samples were collected on day 14 for lactose concentration analysis apart form 24-hour breast milk volume measurement. A milk sample of $50 \mathrm{~mL}$ was obtained in the morning between 8 to $9 \mathrm{AM}$ for each mother by electrical breast pump (Spectra S1; Uzinmedicare Inc., Hwaseong, Korea). The samples were collected in a sterile bottle, transported on ice $\left(4^{\circ} \mathrm{C}\right)$ to the laboratory unit and stored at $-20^{\circ} \mathrm{C}$ in local freezers until analysis. 


\section{Lactose Concentration Analysis}

\section{1) Preparation of Standards}

A high-performance liquid chromatography (HPLC) method was used to determine lactose concentration in breast milk (AOAC [Association of Official Analytical Collaboration] Official Method 980.13). ${ }^{14)}$ Lactose standard was obtained from Sigma-Aldrich Chemical Co. (St. Louis, MO, USA). Standard solution of lactose at a concentration range between $0.005 \%$ and $1 \%$ was prepared and used to create the calibration curve. Prior to injection, all standards were filtered into individual 2 $\mathrm{mL}$ vials through $0.45 \mu \mathrm{m}$ filters to remove any small particles.

\section{2) Sample preparation}

In this study, $2.5 \mathrm{~g}$ of breast milk sample was weighed into centrifuge bottle and $25 \mathrm{~mL}$ petroleum ether was added. Breast milk sample was centrifuged 15 minutes at 1,800 rpm. The supernatant was decanted and discard into a clean test tube. Then, the extraction was repeated 3 times. Afterward, the residue was pulverized with glass rod, $100 \mathrm{~g} \mathrm{H}_{2} \mathrm{O}$ was added and the residue was weighed. The residue was placed in $85^{\circ} \mathrm{C}-90^{\circ} \mathrm{C} \mathrm{H}_{2} \mathrm{O}$ bath 25 minutes and then cooled to room temperature. $\mathrm{H}_{2} \mathrm{O}$ was added to original weight. Then, the residue was centrifuged 10 minutes at 2,000 rpm with draw portion of clear supernatant and filtered into individual $2 \mathrm{~mL}$ vials using $0.45 \mu \mathrm{m}$ filters. After that,

Table 2. Subject characteristics

\begin{tabular}{|c|c|c|c|}
\hline Characteristic & ORC group ( $\mathrm{N}=11)$ & NLC group ( $N=9$ ) & P-value \\
\hline \multicolumn{4}{|l|}{ Maternal characteristics } \\
\hline Age $(y)$ & $30.6 \pm 3.0$ & $32.4 \pm 4.0$ & 0.268 \\
\hline $26-30$ & $5(45.5)$ & $4(44.4)$ & \\
\hline $31-35$ & $5(45.5)$ & $2(22.2)$ & \\
\hline $36-40$ & $1(9.1)$ & $3(33.3)$ & \\
\hline Parity (times) & & & 0.305 \\
\hline 2 & $4(36.4)$ & $5(55.6)$ & \\
\hline $3-4$ & $7(63.6)$ & $4(44.4)$ & \\
\hline Gestational age (wk) & $38.5 \pm 1.6$ & $38.8 \pm 1.5$ & 0.652 \\
\hline Education (y) & $10.4 \pm 2.1$ & $11.4 \pm 2.7$ & 0.260 \\
\hline Family size (people) & & & 0.631 \\
\hline Small $(\leq 4)$ & $5(45.5)$ & $5(55.6)$ & \\
\hline Medium (5-7) & $6(54.5)$ & $4(44.4)$ & \\
\hline $\operatorname{Big}(\geq 8)$ & 0 & 0 & \\
\hline Wealth status & & & 0.375 \\
\hline Poor & $5(45.5)$ & $1(11.1)$ & \\
\hline Non poor & $6(54.5)$ & $8(88.9)$ & \\
\hline Body mass index $\left(\mathrm{kg} / \mathrm{m}^{2}\right)$ & $26.03 \pm 2.95$ & $28.23 \pm 4.64$ & 0.212 \\
\hline Body fat percentage (\%) & $33.43 \pm 3.98$ & $36.08 \pm 5.28$ & 0.216 \\
\hline Prolactin level (ng/mL) & $149.66 \pm 70.27$ & $194.83 \pm 94.12$ & 0.235 \\
\hline \multicolumn{4}{|l|}{ Infant characteristics } \\
\hline Gender & & & 0.199 \\
\hline Male & $3(27.3)$ & $5(55.6)$ & \\
\hline Female & $8(72.2)$ & $4(44.4)$ & \\
\hline Weight (kg) & $3,190 \pm 292.87$ & $3,415.56 \pm 487.97$ & 0.216 \\
\hline Length $(\mathrm{cm})$ & $51.06 \pm 1.64$ & $51.63 \pm 2.09$ & 0.496 \\
\hline Head circumference $(\mathrm{cm})$ & $34.37 \pm 1.44$ & $34.40 \pm 1.74$ & 0.970 \\
\hline
\end{tabular}

Values are presented as number (\%) or mean \pm standard deviation. ORC, original cookies; NLC, Galohgor nutraceutical lactation cookies.
$10 \mu \mathrm{L}$ of prepared sample was then injected onto the HPLC.

\section{Statistical Analysis}

Difference of quantitative variables, according to their distribution, was analyzed with the parametric Independent T-test or the non-parametric Mann-Whitney U-test. To account for the potential effect of galohgor cookies on final outcome variables of the 14 days lactation period were estimated by analysis of covariance analysis. The results of outcome variable, i.e., breast milk volume and lactose concentration are reported as adjusted mean value and lower-upper limit of $95 \%$ confidence intervals (CI). Meanwhile, the subject's characteristics and dietary intake are reported as mean values and standard deviation. In all statistical comparisons, differences with $\mathrm{P}<0.05$ were considered significant.

\section{RESULTS}

\section{Subjects Characteristic}

Characteristics of mother-infant pairs are elaborated in Table 2. Maternal age, parity, gestational age, education, family size, wealth status, BMI, and body fat percentage, and prolactin concentrations were not significantly different between two groups. Furthermore, infant characteristics such as gender, weight, length, and head circumference of these two groups are also not significantly different.

\section{Macronutrient Intake}

Table 3 shows estimated dietary intake of mothers during intervention period. Concerning the intake value of energy, fat, and carbohydrate, no significant difference between the two groups were observed. Meanwhile, the intake value of protein was significantly different in both groups.

\section{Breast Milk Production}

The 24-hours breast milk volume were measured on day 14 postpartum and the results are shown in Figure 2. The result shows that the mean of breast milk volume in intervention group of NLC is significantly higher than ORC $(557.0 \mathrm{~mL} / \mathrm{d}$ [95\% CI, 497.3-616.6 mL/d] versus $435.9 \mathrm{~mL} / \mathrm{d}$ [95\% CI, 382.3-489.6 mL/d]) after being adjusted for parity, gestational age and head circumference of infants.

Table 3. Macronutrient intake of mothers

\begin{tabular}{lccc}
\hline \multicolumn{1}{c}{ Nutrient } & ORC group $(\mathrm{N}=11)$ & NLC group (N=9) & P-value \\
\hline Energy $(\mathrm{kcal})$ & $2,294 \pm 526$ & $1,916 \pm 493$ & 0.117 \\
Protein $(\mathrm{g})$ & $78.6 \pm 27.8$ & $56.2 \pm 5.6$ & $0.045^{\star}$ \\
Fat $(\mathrm{g})$ & $74.1 \pm 25.7$ & $63.6 \pm 21.7$ & 0.341 \\
Carbohydrate $(\mathrm{g})$ & $331.1 \pm 70.4$ & $280.6 \pm 107.8$ & 0.223 \\
\hline
\end{tabular}

Values are presented as mean \pm standard deviation.

ORC, original cookies; NLC, Galohgor nutraceutical lactation cookies. ${ }^{*} \mathrm{P}<0.05$. 


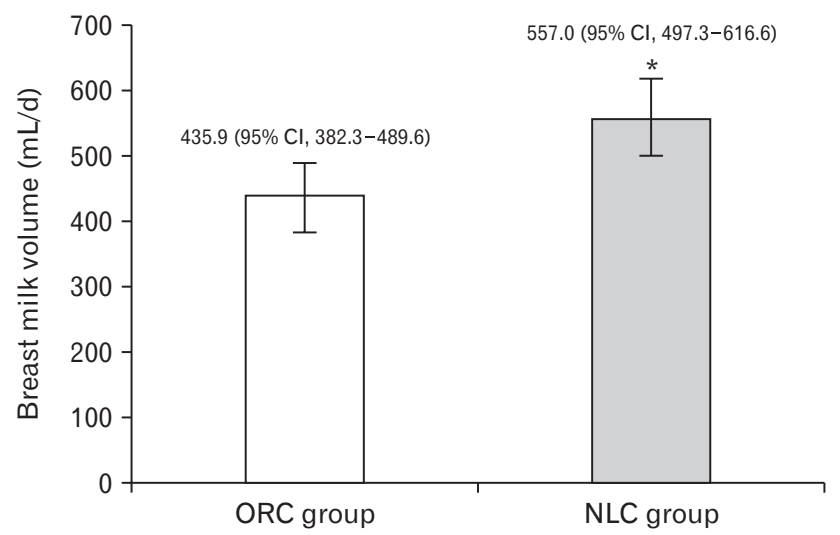

Figure 2. Breast milk volume of the intervention groups. Adjusted mean value and lower-upper limits of $95 \%$ confidence interval $(\mathrm{Cl})$ error bars are presented. Intervention effect was estimated by using adjusted analysis of covariance. The covariates are parity, gestational age, and head circumference of infant. NLC, Galohgor nutraceutical lactation cookies. ${ }^{*} \mathrm{P}<0.05$; significantly higher than original cookies (ORC) group.

\section{Lactose Concentration of Breast Milk}

As shown on Figure 3, the mean concentration of lactose in intervention group of NLC is found significantly higher than ORC (6.03\% [95\% CI, 5.66\%-6.40\%] versus 5.18\% [95\% CI, 4.85\%-5.51\%]) after being adjusted for parity, carbohydrate intake of mother and water content of breast milk.

\section{DISCUSSION}

Breast milk volume measurement is the standard method to assess the performance of breast milk production. Our finding shows that the intervention of NLC significantly affecting on higher breast milk production of NLC compared to ORC (557.0 mL/d [95\% CI, 497.3-616.6 mL/d] versus $435.9 \mathrm{~mL} / \mathrm{d}$ [95\% CI, 382.3-489.6 mL/d]; $\mathrm{P}<0.05$ ). In accordance with our previous animal study, the milk production of galohgor groups were significantly higher than control groups on day 7 of lactation period of rats. ${ }^{15)}$

The 24-hours breast milk production of NLC group was within the normal range for established lactation (440 to 1,220 mL/d) during the second week after birth. ${ }^{16)}$ The average of breast milk production NLC group (557.0 mL/d [95\% CI, 497.3-616.6 mL/d]) in this study result is higher compared to the data of galactagogue intervention presented by several studies. In the study of Swafford and Berens, ${ }^{17)} 10$ mothers consumed three cups of fenugreek daily for 2 weeks intervention. Their results showed that breast milk production increased from 207 $\mathrm{mL} / \mathrm{d}$ in the first week to $464 \mathrm{~mL} / \mathrm{d}$ in the second week. Damanik et al. ${ }^{18)}$ revealed that during the last 2 weeks of Coleus amboinicus or "torbangun" supplementation (from day 14 to day 28), the 24-hour breast milk volume was significantly increased from 361 to $479 \mathrm{~mL}$, or with the average increase of $65 \%$. In addition, the differences between results of previous studies with our present study may be due to the type of nutraceuticals or galactagogue, the dosage, and intervention

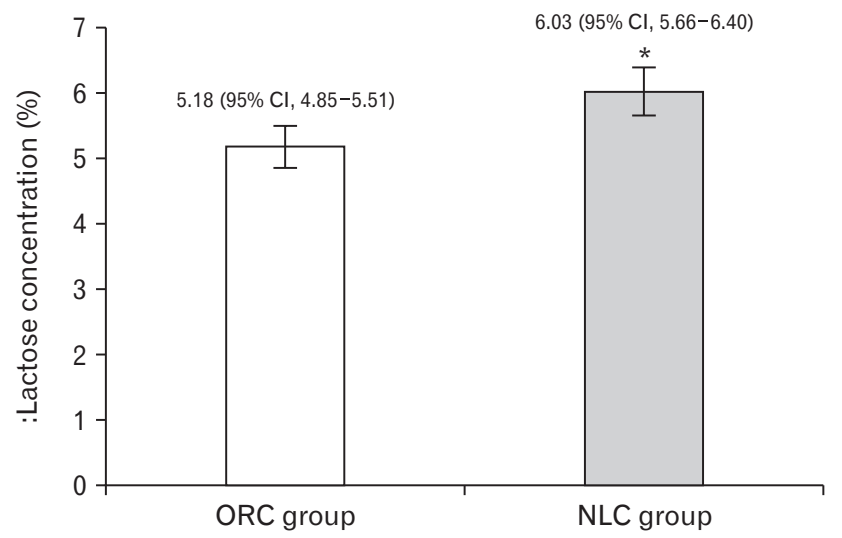

Figure 3. Lactose concentration of the intervention groups. Adjusted mean value and lower-upper limits of 95\% confidence interval $(\mathrm{Cl})$ error bars are presented. Intervention effect was estimated by using adjusted analysis of covariance. The covariates are parity, water content of breast milk, and carbohydrate intake of mother. NLC, Galohgor nutraceutical lactation cookies. ${ }^{*} \mathrm{P}<0.05$; significantly higher than original cookies (ORC) group.

periods. However, the method of the calculating breast milk production was similar.

The mechanism of galohgor effect on increasing breast milk production has been elaborated by several studies that compromised each other. According to Roosita et al..$^{5)}$ and Ma'rifah et al. ${ }^{19)} \beta$-carotene is the most carotenoid compound present in galohgor nutraceuticals. Our previous in vitro study showed $\beta$-carotene plays an essential role in the physiological function of mammary gland differentiation. ${ }^{5)} \mathrm{Ga}-$ lohgor influenced aldehyde dehydrogenase (ALDH1A2) gene expression which plays important roles in the metabolism of $\beta$-carotene. ${ }^{20)}$ $\beta$-carotene is absorbed in the small intestine in the form of retinol and transported in blood attached to retinol-binding protein. Inside the cells, retinol is oxidized into its main biologically active derivatives, retinaldehyde (retinal) and retinoic acid. After conversion of $\beta$-carotene to retinal which is catalyzed by $\beta$-carotene-15-15-dioxygenase, ALDHs catalyzes retinal oxidation to retinoic acid. ${ }^{21,22)}$ Retinoic acid is an important regulator of cell differentiation and plays a major role in embryonic development and tissue remodeling. The biological action of retinoic acid is mediated by three nuclear receptors, $\operatorname{RAR} \alpha, \beta$, and $\gamma$, which are ubiquitously expressed in the breast. Moreover, several studies have shown that retinoic acid signaling is required for development of the mammary gland after birth. ${ }^{23)}$

Furthermore, our previous study showed that $\beta$-carotene increased mammosphere development, genes expression of connexin ( $\mathrm{Cx} 43)$ and $\beta$-casein (Csn2) of the mammary gland cell line (HC11). Connexin is a protein that develops gap junction structure in neighboring mammary epithelial cell, meanwhile casein (major milk protein) gene expression is an important marker for lactogenesis. ${ }^{5)}$ Thus, $\beta$-carotene is an important compound that explains the mechanism of nutraceutical galohgor effect on mammary gland differentiation. An appropriate dietary intake of $\beta$-carotene during lactation together with the inter tissue flux of different nutrients in the gland during lactation influence 
vitamin A concentration in breast milk. ${ }^{23)}$ Galohgor nutraceutical also have beneficial effects on health status of breastfeeding mothers by improving $\beta$-carotene serum levels and oxidative stress. ${ }^{19)}$ Tanaka et al. ${ }^{24)}$ suggested that oxidative stress, a consequence of redox imbalance, has been associated quantity and quality of milk.

Breast milk composition varies considerably within and between mothers and even within a single milk expression.

Our finding shows that consumption of NLC during early postpartum is significantly affecting on higher lactose concentration on breast milk compared to ORC (6.03\% [95\% CI, 5.66\%-6.40\%] versus 5.18\% [95\% CI, 4.85\%-5.51\%; $\mathrm{P}<0.05$ ) on day 14 th of lactation. This result is also comparable with two studies of lactose concentration on breast milk which collected from day 11 th to 28 th of lactation was $6.50 \%,{ }^{25}$ ) whilst for 2 months of lactation was $6.53 \% \pm 0.34 \%{ }^{26)}$ According to Arthur et al. ${ }^{11)}$ high concentration of lactose in milk implies that lactogenesis II has occurred and milk synthesis tends to be higher.

Lactose concentration was influenced by lactation period, breastfeeding pattern, and mother's or offspring's characteristics. ${ }^{10)}$ Lactose production is the highest in the fourth to 7 month, after which it decreases, whilst a gradual increase in the lipid concentration occurs over lactation. ${ }^{27)}$ However, Aumeistere and Zavadska ${ }^{26)}$ revealed that lactose concentration in mature milk is stable and insensitive to changes. According to Khan et al. ${ }^{28)}$ during the established lactation, higher concentration of lactose in breast milk is associated with higher 24-hour breast milk volumes and higher breastfeeding frequency. Meanwhile Dewey et al. ${ }^{29)}$ and Verd et al. ${ }^{30)}$ revealed that when breast milk volume felt down below $200 \mathrm{~mL} / \mathrm{d}$, the lactose, calcium, and zinc decreased whereas protein and sodium increased.

The study showed that the adverse effects were not found in both mothers and infants. The researchers interviewed the mothers regarding the adverse effects of NLC and ORC, including headache, rash, itching, nausea, abdominal pain, and excessive rectal gas. Some previous study reported that galohgor is safe for consumption based on survey in community. ${ }^{3)}$

The differences between the NLC and ORC groups in the changes of lactose concentration as the results of galohgor effect was compromised with the enhancement of breast milk production. Nevertheless, there were some limitations of this study; this study has a small sample and had a short study duration of only 2 weeks. The strength point of this study was the new finding of galohgor nutraceutical cookies administration that provide positive effects in breast milk volume and lactose concentration of postpartum mothers in Indonesia. This study also used a 24-hour test weighing method, which is considered as the gold standard for measuring breast milk volume. In addition to the use of galohgor as nutraceutical, the importance of lactation counseling should be never ignored.

In conclusion, NLC can be recommended as traditional nutraceutical to increase breast milk volume and lactose concentrations in the early postpartum period.

\section{CONFLICT OF INTEREST}

No potential conflict of interest relevant to this article was reported.

\section{ACKNOWLEDGMENTS}

This study was financially supported by Ministry of Research, Technology and Higher Education of Republic Indonesia through LPPM, IPB University, for which we would like to express our gratitude and appreciation. We are also grateful to Almira Nuraelah and Humairoh Sholehah for their assistance in the data collection. The authors also greatly appreciate the kind cooperation from Public Health Office of Bogor City, the midwifes and nurses at primary health care center of Kayumanis, Cipaku, Pancasan, and Warung Jambu in Bogor City, cadres, and subjects in the studied communities.

\section{ORCID}

Katrin Roosita: https://orcid.org/0000-0002-0734-7336

Bahriyatul Ma'rifah: https://orcid.org/0000-0002-9153-2429

Naufal Muharam Nurdin: https://orcid.org/0000-0002-0532-9492

Faisal Anwar: https://orcid.org/0000-0001-5081-9696

\section{REFERENCES}

1. World Health Organization. Global strategy for infant and young child feeding. Geneva: World Health Organization; 2003.

2. Kent JC, Gardner H, Geddes DT. Breastmilk production in the first 4 weeks after birth of term infants. Nutrients 2016;8:756.

3. Dahlianti R, Nasoetion A, Roosita K. Health care and medicinal herbs consumption pattern of postpartum mothers at Sukajadi village, subdistrict Tamansari, Bogor. Media Gizi Kel 2005;29:32-7.

4. Roosita K, Kusharto CM, Sekiyama M, Fachrurozi Y, Ohtsuka R. Medicinal plants used by the villagers of a Sundanese community in West Java, Indonesia. J Ethnopharmacol 2008;115:72-81.

5. Roosita K, Rimbawan SM, Djuwita I, Damanik MR, Kusharto CM, Damayanthi E, et al. $\beta$-carotene roles in proliferation and differentiation, connexin and $\beta$-casein gene expression of mammary gland cells line. Malays J Nutrit 2014;20:113-9.

6. Elliott R. Mechanisms of genomic and non-genomic actions of carotenoids. Biochim Biophys Acta 2005;1740:147-54.

7. Livny O, Kaplan I, Reifen R, Polak-Charcon S, Madar Z, Schwartz B. Lycopene inhibits proliferation and enhances gap-junction communication of KB-1 human oral tumor cells. J Nutr 2002;132:3754-9.

8. Neville MC. Introduction: tight junctions and secretory activation in the mammary gland. J Mammary Gland Biol Neoplasia 2009;14:26970.

9. Talhouk RS, Elble RC, Bassam R, Daher M, Sfeir A, Mosleh LA, et al. Developmental expression patterns and regulation of connexins in the mouse mammary gland: expression of connexin30 in lactogenesis. Cell Tissue Res 2005;319:49-59.

10. Andreas NJ, Kampmann B, Mehring Le-Doare K. Human breast milk: 
a review on its composition and bioactivity. Early Hum Dev 2015;91:629-35.

11. Arthur PG, Smith M, Hartmann PE. Milk lactose, citrate, and glucose as markers of lactogenesis in normal and diabetic women. J Pediatr Gastroenterol Nutr 1989;9:488-96.

12. Roosita K, Wientarsih I, Sa'diah S. The formula and method of HONEY-GALOHGOR: Patent IDP00058958; 2019 May 21, Indonesia. Jakarta: Directorate General of Intellectual Property; 2019.

13. Brown KH, Black RE, Robertson AD, Akhtar NA, Ahmed G, Becker S. Clinical and field studies of human lactation: methodological considerations. Am J Clin Nutr 1982;35:745-56.

14. AOAC Official Method. Fructose, glucose, lactose, maltose and sucrose in milk chocolate: liquid chromatography method: cacao bean and its product. Rockville (MD): AOAC International: 2006.

15. Roosita K, Kusharto CM, Kusumorini N. The effect of traditional herbs medicine "Galohgor" on uterus involution and milk production of Rats (Rattus sp.) made in Sukajadi village, Tamansari Subdistrict, Bogor, Indonesia. Proceedings of International Symposium on Biomedicines; 2003 Sep 18-19; Bogor, Indonesia. Bogor: Biopharmaca Research Center, Bogor Agricultural University; 2004.

16. Kent JC, Mitoulas LR, Cregan MD, Ramsay DT, Doherty DA, Hartmann PE. Volume and frequency of breastfeedings and fat content of breast milk throughout the day. Pediatrics 2006;117:e387-95.

17. Swafford S, Berens P. Effect of fenugreek on breast milk production. Proceedings of the 5th International Meeting of the Academy of Breastfeeding Medicine; 2000 Sep 11-13; Tucson, USA. Chicago (IL): Academy of Breastfeeding Medicine; 2000.

18. Damanik R, Wahlqvist ML, Wattanapenpaiboon N. Lactagogue effects of Torbangun, a Bataknese traditional cuisine. Asia Pac J Clin Nutr 2006;15:267-74.

19. Ma'rifah B, Roosita K, Sinaga T. The Galohgor nutraceutical cookies effects on $\beta$-carotene serum and oxidative stress of postpartum mothers. Prev Nutr Food Sci 2019;24:381-6.
20. Roosita K, Martopuro RS, Djuwita I, Damanik MR, Kusharto CM, Tani F. Biological response of epithelial cells line (CMT-93) induced by $\beta$-carotene. Pak J Nutrit 2013;12:615-9.

21. Jackson B, Brocker C, Thompson DC, Black W, Vasiliou K, Nebert DW, et al. Update on the aldehyde dehydrogenase gene (ALDH) superfamily. Hum Genomics 2011;5:283-303.

22. Duester G. Families of retinoid dehydrogenases regulating vitamin A function: production of visual pigment and retinoic acid. Eur J Biochem 2000;267:4315-24.

23. Cabezuelo MT, Zaragoza R, Barber T, Vina JR. Role of vitamin A in mammary gland development and lactation. Nutrients 2019;12:80.

24. Tanaka M, Kamiya Y, Suzuki T, Kamiya M, Nakai Y. Relationship between milk production and plasma concentrations of oxidative stress markers during hot season in primiparous cows. Anim Sci J 2008;79: 481-6.

25. Broka L, Daugule I, Ciprovica I, Kviluna D, Rumba-Rozenfelde I. Comparison of breast milk composition among lactating women in Latvia. Proc Latv Acad Sci Sect B 2016;70:47-50.

26. Aumeistere L, Zavadska D. Raising awareness about breast milk composition among women in Latvia. J Breastfeed Biol 2016;1:21-7.

27. Kader MM, Bahgat R, Aziz MT, Hefnawi F, Badraoui MH, Younis N, et al. Lactation patterns in Egyptian women. II. Chemical composition of milk during the first year of lactation. J Biosoc Sci 1972;4:403-9.

28. Khan S, Hepworth AR, Prime DK, Lai CT, Trengove NJ, Hartmann PE. Variation in fat, lactose, and protein composition in breast milk over 24 hours: associations with infant feeding patterns. J Hum Lact 2013;29:81-9.

29. Dewey KG, Finley DA, Lonnerdal B. Breast milk volume and composition during late lactation (7-20 months). J Pediatr Gastroenterol Nutr 1984;3:713-20.

30. Verd S, Ginovart G, Calvo J, Ponce-Taylor J, Gaya A. Variation in the protein composition of human milk during extended lactation: a narrative review. Nutrients 2018;10:1124. 